\title{
GugurNya HAD JARímaH PENCURIAN SEBAB TAUbat PERSPEKTIF JAMAL AL-BANNA
}

\author{
Ali Mutowif Graha PBNU Lt. 5 PP IPNU Jl. Kramat \\ al.1199@yahoo.com Raya No.164 Jakarta Pusat
}

\begin{abstract}
This paper provides legal sanction on perperator of crime (jarimah) as a deviational behavior of human. The heavy or light punishment of crime is divided into three, namely: 1) criminal wounding (jarîmah hudûd); 2) criminal killing (jarîmah qisâs and diyat); and 3) criminal offence (jarimah ta'zîr). Jamal al-Banna said that there is a dialectical relationship between individual liberty and public benefit that is controlled by criminal law. This dialectical relationship is similar to the dialectical relationship between faith (aqidah) and the law in Islam. This proves that wisdom of the application of the criminal act in Islam is to control the handling crime to its root. The criminal penalty as described above can be said to be the best, not only to maintain the authenticity or justice but also to protect the public. The term of repentance is certainly relevant to those who make mistake only once because of forgotten or do not know.
\end{abstract}

Keywords: Criminal act, Jamal al-Banna, repentance.

Abstrak: Jarîmah merupakan perilaku manusia yang menyimpang dari larangan norma hukum dan ketika melakukannya diberi sanksi. Adapun Presfektif berat ringannya dalam hukuman, jarîmah di bagi menjadi tiga, yaitu: (1) Jarîmah hudûd (2) Jarîmah qisâs dan diat (3) Jarîmah ta'zîr. Jamal al-Banna mengatakan bahwasanya ada hubungan dialektis antara kebebasan individual dan kemaslahatan publik itu dikendalikan oleh hukum pidana. Hubungan dialektis ini hampir sama dengan hubungan dialektis antara aqidah dan syariat yang ada dalam Islam, ini membuktikan bahwa pidana dalam Islam mempunyai hikmah yaitu Islam mengendalikan penanganan kriminal ini sampai pada akar-akarnya. Hukuman pidana yang telah dipaparkan di atas bisa dikatakan terbaik, bukan hanya untuk menjaga otentisitas, atau keadilan untuk melindungi masyarakat. Istilah taubat tentunya relevan untuk mereka yang melakukan kesalahan hanya sekali, mungkin karena lupa atau tidak tahu, bukan berkali-kali. Oleh karenanya Allah mengatakan: "Sesungguhnya taubat kepada Allah hanya untuk mereka yang melakukan keburukan, karena tidak mengetahui kemudian tidak lama dia langsung bertaubat."

Kata Kunci: Jarîmah, Jamal al-Banna, taubat. 


\section{Pendahuluan}

Manusia yang telah diciptakan Allah swt sebagai makhluk sosial dalam kehidupannya sehari-hari, mereka tidak akan mampu mandiri tanpa kehadiran orang lain. Kehidupan semacam ini dikenal dengan istilah hidup bermasyarakat. Dalam hidup bermasyarakat seseorang secara sadar telah melakukan hubungan satu sama lain sesuai dengan kepentingan mereka masing-masing. Karena dalam kehidupan ini, kepentingan satu sama lain tidak mesti sama, maka sering terjadi benturan-benturan yang menyebabkan berkurangnya keharmonisan dalam hubungan masyarakat bahkan tidak jarang terjadi perselisihan yang sangat sengit yang berakibat saling membunuh satu sama lain. Dengan adanya benturan semacam itulah timbul juga kejahatankejahatan yang dampaknya tidak hanya merugikan diri sendiri atau pelaku, tetapi juga merugikan korban dan masyarakat luas.

Modernisasi yang menyentuh berbagai lapisan masyarakat dan merambah ke sudut belahan dunia memunculkan berbagai problem sosial bagi masyarakat yang belum siap. Hal tersebut menimbulkan krisis dalam kehidupan, persaingan yang semakin ketat dan ongkos hidup yang semakin mahal memaksa masyarakat sedikit demi sedikit meninggalkan nilai-nilai yang paling teguh dengan alasan mempertahankan hidup yang semakin sulit. Alasan itulah yang sering kali melegitimasi masyarakat melakukan berbagai tindak kejahatan seperti pembunuhan, perampokan, pencurian, dan lain sebagainya.

Untuk menjaga keharmonisan dan kesejahteraan bersama dalam rangka mencapai keinginan masing-masing pihak, maka manusia membuat aturan-aturan yang disepakati bersama, aturan-aturan yang harus dipatuhi dan dijunjung tinggi oleh seluruh anggota masyarakat yang dinamakan dengan hukum. Agar hukum itu dapat dipatuhi dan diterima oleh seluruh anggota masyarakat, maka hukum tersebut harus sesuai dan tidak bertentangan dengan asas-asas keadilan masyarakat di mana hukum itu berlaku.

Paradigma di atas sesuai dengan nilai-nilai yang dibawa oleh Islam, agama universal yang mengandung ajaran-ajaran dasar yang berlaku untuk semua tempat dan segala zaman. Islam datang untuk membimbing manusia dalam upaya mencapai kebahagiaan dunia dan akhirat. Oleh karena itu tujuan sebenarnya dari agama Islam adalah untuk membina manusia dalam fisik maupun mental. Intisari agama- 
agama khususnya Islam berkisar pada baik dan buruk yaitu perbuatan mana yang baik membawa kebahagiaan, dan perbuatan yang bersifat buruk dan jahat membawa kemudharatan.

Dalam Islam, hak milik kaum muslimin tidak terkecuali harta benda dilindungi, karena harta benda adalah bahan pokok untuk hidup dan dengan harta itu pula kita berharap untuk dapat menjunjung tinggi agama kita yakni Islam. Islam juga melindungi hak milik individu manusia sehingga hak milik tersebut benar-benar merupakan hak milik yang aman, dengan demikian Islam tidak menghalalkan seseorang merampas hak milik orang lain untuk dimiliki secara melawan hukum dengan dalih apapun sebagai perbuatan yang batal.

Islam telah mengharamkan mencuri, mencopet, korupsi, riba dan sebagainya, karena Islam ingin membangun umat yang sehat dengan tujuan membina kedamaian dalam masyarakat. Memakan hak milik orang lain itu berarti memakan barang haram sebagaimana firman Allah swt dalam surat al-Baqarah ayat 188 .

"Dan janganlah sebagaian kamu mamakan harta sebagian yang lain di antara kamu dengan jalan yang batil dan (janganlah) kamu membawa urusan harta itu kepada hakim, supaya kamu dapat memakan sebagian dari pada harta benda orang lain itu dengan jalan berbuat dosa, padahal kamu mengetahui."

\section{Jarîmah Had Pencurian}

Hukum pidana Islam merupakan segala ketentuan hukum mengenai tindak pidana atau perbuatan kriminal yang dilakukan oleh orang-orang mukallaf (orang yang dibebani kewajiban), sebagai hasil pemahaman atas dalil-dalil hukum dari al-Qur'an dan hadis. Dalam hukum pidana Islam, hukum kepidanaan atau disebut juga dengan jarîmah (perbuatan tindak pidana). Jarîmah sendiri terbagi menjadi dua yaitu (1) Jarîmah hudûd adalah perbuatan pidana yang mempunyai bentuk dan batas hukumannya di dalam al-Qur'an dan hadis, adapun sanksinya berupa rajam, jild, potong tangan, penjara atau kurungan seumur hidup, pengasingan dan salib. (2) Jarîmah ta'zîr adalah perbuatan pidana yang mempunyai bentuk dan ancaman hukuman yang ditentukan oleh penguasa (hakim) sebagai pelajaran kepada pelakunya.

\footnotetext{
${ }^{1}$ Sayyid Sabiq, Fiqih Sunnah, Jilid IX, terj. Moh Nabhan Husain (Bandung: al-Ma'arif, 1984), 213.
} 
Hukumannya berupa penjara, pemecatan, ganti rugi dan hukuman lain yang sesuai dengan pelanggaran yang dilakukan. ${ }^{2}$

Pengertian Pencurian secara etimologis yaitu, pencurian asal kata dari saraqa yasriqu-saraqan, wa sariqan wa saraqatan, wa sariqatan wa sirqatan, yang berarti mengambil sesuatu secara sembunyi-sembunyi atau secara terang-terangan. Ulama mengkategorikan pencurian kepada 2 (dua) macam yaitu pencurian yang diancam dengan hukuman ta'zîr adalah pencurian yang tidak terpenuhi syarat-syarat pelaksanaan hukuman Had. Ulama juga mengkategorikan pencurian yang diancam dengan hukuman had, kepada 2 (dua) bagian yaitu pencurian kecil dan pencurian besar.

Adapun yang dimaksud dengan pencurian kecil secara terminologis adalah: Menurut Abd al-Qadir Audah Pencurian kecil adalah mengambil harta orang lain secara sembunyi-sembunyi, sedangkan menurut al-Sayid Sabiq yaitu, pencurian kecil adalah pencurian yang wajib divonis dengan potongan tangan dan dimaksud dengan pencurian besar secara terminologis menurut Abd al-Qadir Audah dan al-Sayid Sabiq yaitu, pencurian besar adalah mengambil harta orang lain dengan kekerasan dan ini disebut juga dengan merampok atau begal.

Syarat-syarat Pencuri Menurut al-Sayid Sabiq, bahwa syarat-syarat pencuri yang divonis dengan sanksi potong tangan adalah sebagai berikut: a) Taklif (cakap hukum). yaitu, pencuri tersebut sudah balig dan berakal maka tidak divonis potong tangan pencuri gila, anak kecil, karena keduanya tidak mukalaf, tapi anak kecil yang mencuri dapat sanksi yang bersifat mendidik (ta'zîr). b) Kehendak sendiri atau ikhtiar yaitu, bahwa pencuri tersebut mempunyai kehendak sendiri. Seandainya ia terpaksa untuk mencuri, maka tidak dianggap sebagai pencuri, karena paksaan meniadakan ikhtiar tidak adanya ikhtiar menggugurkan taklif. c) Sesuatu yang dicuri itu bukan barang syubhat yaitu, sesuatu yang dicuri itu bukan barang syubhat, jika barang tersebut syubhat, maka pencuri itu tidak divonis potong tangan, oleh karena itu orang tua (Bapak-Ibu) yang mencuri harta anaknya, tidak divonis potong tangan, berdasarkan hadis Nabi Muhammad saw: Kamu dan hartamu milik Bapakmu.

Rukun pencurian adalah sesuatu yang sangat urgen sehingga bila salah satu rukun dari pencurian tidak ada, maka pencurian itu dianggap

\footnotetext{
2 Teguh Prasetyo, Hukum Pidana (Jakarta: Rajawali Pers, 2010), 12-13.
} 
bukan sebagai pencurian yang sempurna jika pencurian tersebut dianggap bukan sebagai pencurian yang sempurna, maka secara otomatis hukuman had bagi pencuri yaitu potong tangan tidak akan dieksekusi.

Rukun pencurian menurut Abdul Qadir Audah ada 4 (empat) yaitu sebagai berikut: a) Mengambil secara sembunyi-sembunyi atau secara diam-diam b) Sesuatu yang diambil itu adalah harta. c) Harta tersebut milik/kepunyaan orang lain. d) Ada maksud/niat jahat, atau niat berbuat tindak pidana (mencuri). ${ }^{3}$

\section{Biografi Singkat Jamal al-Banna}

Nama asli Jamal al-Banna adalah Ahmad Jamal al-Din. Ia lahir pada tanggal 15 Desember 1920 di Mahmudiyyah, sebuah desa yang terletak di propinsi Bukhayrah, sekitar 50 kilometer dari kota wisata Alexanderia, Mesir. Pemikir ini merupakan anak laki-laki terakhir dari delapan bersaudara keluarga alBanna. Kakaknya yang tertua, Hasan alBanna, adalah pendiri jam'iyyah al-Ikhwan al-Muslimûn. Ayahnya bernama Ahmad b. 'Abd. al-Rahman b. Muhammad al-Banna al-Sa'ati, atau yang biasa dipanggil Shaykh al-Banna.264 Ibunya bernama Ummu Sa'ad Saqar. Konon, orang tuanya memberikan nama Ahmad Jamal alDin, agar kelak setelah besar anaknya menjadi sosok revolusioner dalam usaha pembaruan Islam seperti Jamal al-Din al-Afghani. Bahkan, tidak jarang ayahnya memanggil Jamal dengan nama "al-Afghani". Hal itu pula yang mengilhami Jamal untuk bisa melakukan pembaruan keagamaan seperti yang sudah pernah dilakukan oleh Jamal al-Din alAfghani.

Karir politik-intelektual Jamal al-Banna dimulai ketika ia mendirikan Hizb al-'Amal al-Watani al-Ijtima'i (Partai Buruh Nasionalis-Sosialis) pada 1946. Partai yang dipimpinnya ini didominasi oleh pemuda dan buruh. Ia dan para anggota partai aktif menyebarkan selebaran yang menuntut hak dan nasib kaum buruh. Namun, iklim politik yang tidak kondusif membuat Jamal sering berurusan dengan pemerintah. Gerakannya semakin dipersempit hingga partainya pun dibubarkannya. Ia sempat ditawari oleh kakaknya menjadi anggota alIkhwan al-Muslimun namun ia menolaknya.

\footnotetext{
${ }^{3}$ Mardani, "Sanksi Potong Tangan Bagi Pelaku Tindak Pidana Pencurian Dalam Perspektif Hukum Islam", Jurnal Hukum, No. 2 Vol. 15 April 2008, 241-249.
} 
Pada proses perjalanan intelektualnya Jamal masih terus memberikan perhatiannya terhadap nasib kaum buruh, namun semenjak sweeping pemerintah yang anarkis terhadap aktivitas politiknya, ia memutuskan untuk 'berdakwah' lewat buku. Inilah momen yang menandai perjalanan hidupnya sebagai penulis yang produktif. Di sini Jamal mencoba menegaskan bahwa untuk menjadi rasional dan progresif, umat Islam bisa menggali rasioanalitas dari sumber utamanya, al-Qur'an. Seperti inipula yang ditegaskan oleh Hashim Salih-spesialis penerjemah karya-karya Muhammad Arkun dari bahasa Prancis ke bahasa Arab-dalam al-Sharq al-Awsat yang menulis artikel dengan judul "Jamal al Banna Bayn al-Islah al-Dini wa al-Tanwir" (Jamal alBanna antara Reformasi Keagamaan dan Pencerahan) dimana dalam artikel tersebut ia memandang Jamal al-Banna sebagai pemikir yang setelah melalui proses mendekonstruksi ideologi yang bersemayam dalam khazanah turath Islam kemudian digalilah prinsip-prinsip rasionalitas yang bersumber dalam sumber utamanya, alQur'an. Oleh karenanya, Salih kemudian menjulukinya dengan Martin Luther-nya Islam karena kedua tokoh, baik Luther maupun Jamal, sama-sama menggerakkan reformasi keagamaan (al-islah al-dini) dalam agamanya masing-masing.

Konteks pemikiran Jamal al-Banna sendiri diawali dengan keprihatinannya terhadap fenomena tidak adanya demokrasi dan kebebasan dalam dinamika pemikiran Islam. Bahkan, menurutnya, problem absolutisme ini tidak hanya terjadi pada bidang politik tetapi juga sudah merambah bidang agama. Tiap negara Arab memiliki "sang patron" yang memerankan absolutisme dalam bidangnya. Menurut Jamal, pembaruan pemikiran yang dinamai dengan revivalisme-humanis ini dihadirkan untuk menegasikan absolutisme-absolutisme seperti ini. Itulah kenapa dengan pembaruannya ia kemudian menciptakan sebuah paradigma berpikir baru, yakni paradigma humanisme-religius. Paradigma ini tidak lagi hasil dari sebuah iklim absolutisme seperti yang dijalankan oleh ulama, tapi sebuah aturan ijtihad-ijtihad baru yang dihasilkan secara demokratis dengan tetap mengindahkan piranti dasar Islam yang bersumber dari titah ilahi, al-Qur'an. Dengan begitu, paradigma tersebut merupakan upaya konkret Jamal dalam mewujudkan otonomi manusia dengan memulai lebih dahulu dari kebebasan 
berijtihad dalam ranah pemikiran Islam, baik dalam bidang tafsir, hadis, maupun fiqh. ${ }^{4}$

\section{Gugurnya Had Jarîmah Pencurian Menurut Jamal al-Banna}

Pembaruan dalam metodologi hukum Islam (usûl al-fiqh) secara global dilakukan dengan dua cara: pertama, tidak bertaklid kepada suatu metode kecuali dengan dalil dan selalu terbuka untuk mentarjih di antara beberapa pendapat. Kedua, memperluas kaidah-kaidah yang menjadi bahasan dalam ilmu usul fikih. Jamal al-Banna menawarkan kontruksi pemikiran hukum dengan berlandaskan kepada usûl al-fiqh guna memahami hukum Islam secara komprehensif. Langkah pertama yang dilakukan Jamal al-Banna dalam pembaruannya, mendestruksi sumber hukum Islam dengan meletakkan secara maksimal peran akal dalam berijtihad yang mengacu pada prinsip terwujudnya kemashlahatan. Bagi Jamal al-Banna, yang terpenting dalam langkah sebuah pembaharuan bukanlah menafsirkan al-Qur'an akan tetapi mengangkat nilai revolusioner al-Qur'an. Inti ajaran al-Qur'an adalah nilai-nilai universal ajarannya. Peran akal dan kondisi sosial, bagi Jamal al-Banna merupakan dua landasan pokok bagi pemahaman dan penafsirannya terhadap alQur'an. Pemikiran dalam fikih juga menjadi sorotan Jamal al-Banna. Jamal al-Banna memandang bahwa hukum yang ada kurang menunjukkan keuniversalan al-Qur'an dan terkesan tertutup. Hal ini menurut Jamal al-Banna disebabkan pendekatan yang digunakan dalam mengkaji ayat-ayat hukum kurang tepat dan bersifat parsial, aspek keterpaduan ayat kurang diperhatikan. ${ }^{5}$

Berangkat dari sebuah metode istinbât Jamal yakni menggagas fiqh yang kontekstual, humanis serta kebebasan otentik. Maka dalam penerapan hukuman tindak pidana pencurian tidak bisa serta merta langsung diputuskan potong tangan, meskipun sudah ada dalil al-Qur'an yang memperkuat hal itu. Jamal sepakat dengan hukuman potong tangan bagi tindak pidana pencurian, akan tetapi harus prosedural yakni dengan memenuhi empat syarat, sebagai berikut:

\footnotetext{
${ }^{4}$ Mukhammad Zamzami, "Teologi Humanis Jamâl Al-Bannâ: Sebuah Rekonstruksi Epistemologis Studi Keislaman", Teosofi: Jurnal Tasawuf dan Pemikiran Islam, Volume 02, Nomor 01, Juni 2012, 175.

${ }^{5}$ Mufidah Saggaf, "Pembaruan Hukum Islam Menurut Jamal Al-Banna", Disertasi, Jakarta: Sekolah Pascasarjana UIN Syarif Hidayatullah, 2011), ii.
} 
a) Kebijakan penguasa

Penerapan hukum potong tangan harus melalui forum pematangan, dan ini membutuhkan seorang penguasa. Oleh karenanya, penerapan hukum ini tidak dapat dilakukan tanpa adanya penguasa, karena ini dianggap tidak mencukupi persyaratan dalam memberlakukan hukum tersebut.

b) Melihat konteks ruang dan waktu

Potong tangan tidak menjadi satu-satunya hukuman bagi pencurian di semua tempat dan masa, dimana seseorang boleh menggunakan hukuman lain yang mungkin lebih sesuai dengan kondisi ruang dan waktu. Hukuman potong tangan adalah hukuman paling berat dalam pencurian, sementara di bawahnya masih terdapat hukuman yang lebih ringan, seperti penjara dan lainnya. Semua sangat tergantung pada keadaan. Seperti yang pernah dilakukan 'Umar' ketika masyarakat dilanda kemiskinan, maka hukum potong tangan tidak dapat diterapkan dalam suasana seperti ini.

c) Kriteria pencuri

Pertama, pencuri harus dewasa dan berakal.

Kedua, dia harus memahami batasan pencurian yang mewajibkan potong tangan. Bila dia melakukan tanpa pengetahuan sebelumnya, maka tidak wajib potong tangan. Karena seperti yang dikatakan "Umar, hukum pidana bagi yang mengetahuinya".

Ketiga, melakukannya secara suka rela. Bila karena dipaksa atau terpaksa, maka tidak wajib diterapkan. Karena kata Nabi, "Umatku dimaafkan dalam tiga hal: lupa, salah dan keterpaksaan".

Keempat, tidak ditemukan kerancuan antara kedua belah pihak. Seorang anak yang mencuri kekayaan ayahnya tidak harus dipotong, karena bapak mempunyai tanggung jawab nafkah terhadap anaknya. Begitu sebaliknya, Nabi pernah berkata: "kamu dan kekayaanmu milik bapakmu”.

d) Kriteria barang yang dicuri

Pertama, berbentuk kekayaan. Pencurian anak tidak harus dipotong, karena itu bukan kekayaan. Begitu juga dengan pencurian al-Qur'an, kitab-kitab, berhala emas atau perak yang menyerupainya. Ini mengacu pada konsensus yang mengharamkan hal ini. 
Kedua, bisa dipindah dan dikeluarkan. Pencurian halaman rumah, gedung, tanah, tidak harus dipotong tangan, karena semua itu tidak dapat dipindah.

Ketiga, di kawasan perumahan atau dijaga. Pencurian ditempat perdagangan, hotel, restoran, pada waktu kerja tidak wajib potong tangan. Berbeda bila pencurian ini terjadi di luar waktu kerja. Dalam konteks ini, potong tangan diwajibkan. Pencurian barang-barang masjid pun tidak wajib potong tangan kecuali ada penjaganya. Begitu juga dengan pencurian barang-barang orang yang melakukan shalat, kecuali memang dijaga. Begitu juga dengan gereja, tempat peribadatan dan sekolah, karena semua itu tidak termasuk kekayaan.

Keempat, hukum asalnya tidak dibolehkan, seperti ikan, hewan buruan dan yang menyerupainya. Dan tidak cepat rusak seperti daging, buah-buahan, serta sayuran. Begitu juga dengan hasil pertanian seperti jagung, dalam semua itu tidak wajib potong tangan. ${ }^{6}$

\section{Taubat Menurut Jamal al-Banna}

Taubat merupakan solusi untuk pembersihan hati pasca melakukan tindak pidana. Adapun konsep taubat, yang akan diuraikan sebagai berikut:

1. Manajemen Taubat

Adalah cara hamba melakukan proses komunikasi dengan Allah SWT melalui ibadah yang terus menerus dengan cara kembali kepada jalan yang benar sesuai dengan syari'at Islam, jalan yang telah diridhai Allah SWT. Adapun skema manajemen taubat di bawah ini.

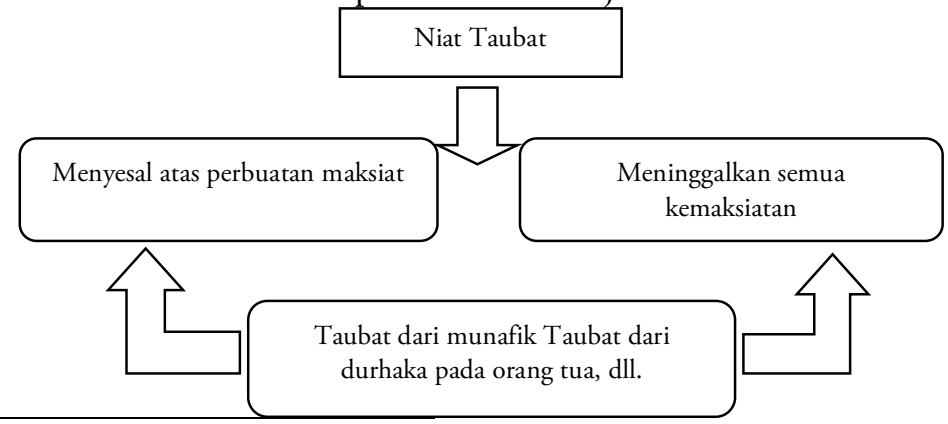

\footnotetext{
${ }^{6}$ Salim Rusydi, Harian ah-Ahali, Edisi, 25/12/1991. Lebih jelasnya bisa dilihat dalam bukunya: Jamal al-Banna, Nahwa Figh Jad d, Vol. 3, terj. Hasibullah Satrawi dan Zuhairi Misrawi, Manifesto Fikih Baru 3; Memahami Fikih Moderat, (Jakarta: Penerbit Erlangga, 2008), 132-133.
} 
Keterangan:

a. Niat

Niat adalah faktor yang menentukan nilai suatu perbuatan baik dan buruknya nilai tergantung pada niat pelakunya.

b. Taubat

Taubat artinya kembali. Jika dihubungkan dengan kenyataan bahwa di dalam kehidupan ini kita suka melanggar larangan-larangan Allah, maka tobat berarti kembali dari larangan allah. Dengan demikian pengertian taubat adalah meninggalkan larangan-larangan Allah dan kembali memenuhi perintahnya.

c. Menyesal atas perbuatan maksiat.

Adalah menyadari akan perbuatan yang telah dilakukannya selama ini, bahwa itu maksiat.

d. Meninggalkan semua kemaksiatan.

Maksudnya pelaku berjanji tidak menjamah ataupun mengulangi perbuatannya.

2. Syarat Taubat

Taubat merupakan perjuangan paling besar dan berat, karena dalam taubat ada perang dahsyat yang terus menerus berkecamuk, yakni perang melawan kecenderungan-kecenderungan nafsu. Ada syarat yang harus dipenuhi dalam taubat hingga ia dipandang sebagai perjuangan paling besar, diantaranya:

a. Ikhlas karna Allah swt, yakni meniatkan taubat semata-mata karena mengharapkan rahmat, hidayah dan karunia dari Allah serta selamat dari azab-Nya.

b. Menyesali perbuatan maksiat yang telah diperbuat dan bertekat untuk tidak melakukannya lagi.

c. Meninggalkan kemaksiatan segera dengan segera. Jika kemaksiatan itu berkaitan dengan hak Allah swt, segera meminta ampun kepada-Nya. Jika kemaksiatan itu berkaitan dengan hak makhluk, segera membebaskan diri darinya, dengan cara mengembalikan hak orang yang bersangkutan, mengembalikan barangnya, atau meminta maafnya. 
3. Tahapan Taubat

a. Bertaubat dari kesalahan dan kemaksiatan yang pernah kita lakukan.

b. Bertaubat dari kealpaan dan kelalain kita mengingat Allah didalam keseharian.

c. Bertaubat dari segala sesuatu yang selain Allah, karena yang selain Allah pasti akan sirna. Hanya keberadaan-Nya yang kekal dan abadi.

\section{Simpulan}

Pemikiran Jamal al-Banna tentang gugurnya had jarîmah pencurian sebab taubat. Adapun gugurnya had jarîmah pencurian sebab taubat dalam konteks pemikiran Jamal al-Banna gugurnya had jarîmah pencurian harus prosedural atas empat syarat yaitu: kebijakan penguasa, melihat konteks ruang dan waktu, kriteria pencuri, barang yang dicuri. Dengan tanpa mencukupi syarat-syarat tersebut Jamal menafikan landasan dasar pada surat al-Maidah ayat 8 karena pembacaannya tentang ayat hukuman bagi perbuatan pencurian Jamal memulai dengan redaksi kata al-sâriq yang menurutnya menjadi penyebab persoalan, kata al-sâriq yang artinya pencuri laki-laki dan al-sâriqah artinya pencuri perempuan. Kedua kata ini merupakan kata sifat, bukan kata benda. Jadi menurut Jamal sebuah sifat akan menjadi label seseorang bila melakukannya secara berulang kali. Sebenarnya Jamal sepakat dengan hukum yang ada pada ayat di atas dengan catatan harus prosedural, yakni memenuhi syarat mulai dari segi: kebijakan penguasa, konteks ruang dan waktu, kriteria pencuri, barang yang dicuri.

Pemikiran Jamal al-Banna tentang gugurnya had jarîmah pencurian sebab taubat disebabkan karena Jamal mewacanakan keadilan, kemaslahatan dan hak asasi manusia sebagai isu kemanusiaan global selalu menjadi isu yang menarik untuk diperbincangkan. Menurut Jamal taubat merupakan solusi dalam pencegahan hukuman potong tangan, akan tetapi Jamal tidak mengeluarkan konsep taubat secara spesifik. Penulis mencoba memberikan tawaran konsep taubat untuk menyempurnakan penelitian dan pemikiran Jamal al Banna, yaitu: (a) Manajemen taubat, (b) Syarat taubat, (c) Tahapan taubat. 


\section{Daftar Rujukan}

Banna (al-), Jamal. Nahwa Fiqh Jadîd, Vol. 3, terj. Hasibullah Satrawi dan Zuhairi Misrawi. Manifesto Fikih Baru 3; Memahami Fikih Moderat. Jakarta: Penerbit Erlangga, 2008.

Kansil, C.S.T. Pengantar Ilmu Hukum dan Tata Hukum Indonesia. cet. Ke-5, Jakarta: Balai Pustaka, 1983.

Mardani. "Sanksi Potong Tangan Bagi Pelaku Tindak Pidana Pencurian Dalam Perspektif Hukum Islam”, Jurnal Hukum, No. 2 Vol. 15 April 2008.

Prasetyo, Teguh. Hukum Pidana. Jakarta: Rajawali Pers, 2010.

Rusydi, Salim. Harian ah-Ahâli, Edisi, 25/12/1991.

Sabiq, Sayyid. Fiqih Sunnah. Jilid IX, terj. Moh Nabhan Husain, Bandung: al-Ma'arif, 1984.

Saggaf, Mufidah. "Pembaruan Hukum Islam Menurut Jamal Al-Banna", Disetasi, Jakarta: Sekolah Pascasarjana UIN Syarif Hidayatullah, 2011.

Zamzami, Mukhammad. "Teologi Humanis Jamâl Al-Bannâ: Sebuah Rekonstruksi Epistemologis Studi Keislaman", Teosofi: Jurnal Tasawuf dan Pemikiran Islam, Volume 02, Nomor 01, Juni 2012. 